\title{
Research on Educational Reform and Development of College Sports under the Background of Modern Education Technology
}

\author{
Hui Li \\ North China Institute of Aerospace Engineering \\ Langfang,Hebei, 065000 China
}

\begin{abstract}
In today's era of striving to develop a variety of educational tools, under the background of modern educational technology, teaching methods get more widespread attention and application for its special features and advantages. It has quick impact on the traditional system of teaching methods to promote the reform of teaching methods. The College Physical Education has its own unique characteristics, for which it is necessary to carry out a research on College Physical Education under the background of modern educational technology.
\end{abstract}

Keywords-Modern educational technology, university, Physical Education

\section{INTRODUCTION}

Task of cultivating innovative, versatile talents, education reform of college determines the quality of personnel training. However, Physical Education reform is not optimistic, we must deepen the reform. Modern educational technology is accompanied by the development of information technology, science and technology and soft science, it is the product of highly developed modern science and technology, it changes the operation and development in all fields of social patterns, it changes lifestyles and learning members of society, it is inevitable to fully apply modern educational technology to deepen the reform of college physical education.

\section{TRENDS OF MODERN EDUCATIONAL TECHNOLOGY}

Modern educational technology is the sum of all technical means of the educational activities in modern society used by people, including the physical and chemical forms and intelligent form (or hard and soft technologies). The development of modern educational technology has experienced three stages of flags: first, Comenius classroom teaching skills; second, audio-visual form of educational technology; Third, the formation of educational technology. From the beginning of the 1960s, the development process that educational technology evolved to modern educational technology showed that its main technical content was produced in this century, it contains more researches about human psychological factors, but also contains the increasing learner attention or respect, of course, it is also widely used in the physical and chemical forms of technological achievements, such as slides, film, television, radio, computers, network systems, the structure has become more complex, covering a wide range. That strengthening teaching management, and other organizations to improve the teaching and learning became more and more rely on the computer to complete the task.

\section{PROBLEMS IN COLLEGE PHYSICAL EDUCATION REFORM}

\section{A. Teaching model is old}

The traditional mode of teaching Physical Education is conducted under the strict management of teachers. Focusing on "three bases" educations, one-sidedly emphasizing on improving students' load intensity, neglecting the cultivation of students' physical ability and interest in sports can not be fully mobilize the initiative of their learning and motivation. Teaching philosophy is still stuck at the level of examination-oriented education, emphasizing on imparting knowledge and intellectual culture and ignoring emotional development, it has not yet been able to come out from examination-oriented education. Quality education, innovation and education, people-centered concept of education has not yet been widely recognized by the whole society.

\section{B. Construction of Teaching Staff is slow}

Teachers are the perpetrators of course teaching, but also the explorers of research of teaching and reform. With the advancement of science and technology and social development, the requirements to the quality of physical education and the operational capacity of teachers are increasingly high. However, the current prevalence of university teachers has following problems: low education levels and the proportion of senior titles. Our PE teachers in universities are around seven million people, in whom the total number of master's degrees proportion reach only $21.8 \%$ compared to other disciplines Masters and Ph.D. in large numbers; it shows a serious problem among low degree of PE teachers. Because of Less educated, with the lower levels of their foreign language level and scientific research level, college teachers with senior professional titles have a low proportion, less than teachers in other disciplines 4.7 to 
16.4 percentage point, which makes a long period of low state--undergraduate training undergraduate, it is not conducive to the further deepening of the reform of physical education and creative talents. Disciplinary expertise is aging and knowledge structure is irrational. At present, what China's majority teachers accept in the physical education in the school is basically sports education system, because of this emphasis on technical education, ignorance of theory education or cross natural science and social science education knowledge, which make these teachers helpless in the face of challenges era of knowledge economy, which became a seriously invisible barriers on Physical Education Reform. the number is relatively lack, in order to accelerate personnel training, reserve personnel, improve the comprehensive national strength, college enrollments are increasing year after year, however, the university faculty can't keep up with the pace of "enrollment" pace, with authorities, school leaders pay less attention to the importance of physical education, then gradually, the situation of the more students with the less physical education teachers appears so that they are overworked, seriously affecting the quality of teaching physical education.

\section{Application of modern educational technology is lag behind}

Modern educational technology provides a new platform and tools for college physical education, it has played a positive role in promoting college physical education, but due to the influence of traditional concepts of physical education and sports practice teaching need to be conducted in the sports arena, these limitations made modern educational technology did not have been carried out extensively in Physical Education.

\section{ADVANTAGES OF MODERN EDUCATIONAL TECHNOLOGY IN PHYSICAL EDUCATION}

\section{A. To watch demonstration of the correct action more directly and intuitively}

One purpose of physical education is to allow students to learn and master the correct technique and movement skills and techniques. In traditional teaching, the teacher only demonstrate personally, but, for various reasons, the teacher may not be very technical in action, besides, let the old teacher personally demonstrate a more severe or relatively difficult high technical movements, that's a little beyond their reach, which is not conducive to student learning. If multimedia assisted instruction on proper technique can be used to record the action down on the screen, and can be played from multiple angles, and slow motion mode can be used to allow students to see more clearly, such as: the forward roll, this lesson will demonstrate the correct operation of the front side, rear loop different angles, while the correct action before the normal playback speed, then slow play. Entire technical process is slowed movement, the students will see more real, pre-roll action, and then the right technology will deeply imprinted in their mind.

\section{B. To make classroom becomes more dynamic}

The use of multimedia assisted teaching enhanced interesting and informative of sports game. In this part of the game, there is a large number of pictures and Sports Tidbits in the courseware, during the match, two students went together to the computer, there will be multiple choice or small quiz game on the screen, students can use the mouse to drag the correct answer, if their answer is correct, a medal will appear on the screen with a burst of applause, if you got it wrong then you need to try it again, so that the students not only get exercise, but also expand their knowledge. In addition, during the relaxation exercises, music was recorded to courseware, the only thing need to do is click the mouse, and music will immediately sounded, and the screen appears a group of cartoon animals dancing with classmates. Students are very interested in such a form, they participated in the highly motivated and atmosphere is dynamic.

\section{To use multimedia technology to stimulate students' interest in learning the sport}

Making use of multimedia technology with its distinctive image and vivid image, flexible screening performance characteristics and rich media features to attract students' attention, novel means show students' associative thinking to the greatest extent, it is consistent with the psychological characteristics of young people, fully meet their psychological needs, and well stimulate their interest in learning.

\section{To help teachers to continuous learning in the teaching process}

Teachers are both expression of information and information processors and handlers, is the soul of the educational process. The use of modern educational technology in teaching presented new challenges to them. Teachers must continuously improve their quality and ability to improve the quality of teaching. Teachers must raise their own level of expertise and increase the depth and breadth of expertise, then they can use other means and methods of teaching. Reform the traditional teaching mode, teaching content, broaden their knowledge, to carry out the quality of education is higher demands on teachers in the new era. Therefore, in addition to learning the professional knowledge of teachers, we must also learn computer information technology, psychology, aesthetics and other knowledge to adapt to the new situation in the 21 st century modernization of education.

\section{NEW IDEAS OF COLLEGE PHYSICAL EDUCATION REFORM AND DEVELOPMENT UNDER THE MODERN PHYSICAL EDUCATIONAL GUIDANCE}

\section{A. The key to change the concept of reform and development of college sports}

With the development and progress of society, many ideas and concepts are in the face of traditional sports education challenges, the underlying factors restrict and affect the current reform is inherent old ideas from the minds 
of college PE teachers. Therefore, for the further development of university sports reform, first of all, you must change the concept from the start.

Establish the concept of lifelong physical education guidelines focus on sports, sports education have formed a consensus. It not only has the profound social background, but also an important symbol to explore the deep-seated reform of college sports physical education. The goal of Physical Education is to train students to be needed people who are physically and mentally adapt society. According to this goal and the "National College of Physical Education Curriculum Guidelines," to build a new system of physical education curriculum is an important issue.

\section{B. It's an important part to fully exploit the innovation to improve the quality of physical education}

It is a important condition to create a new sound system and a set of new mechanisms and Physical Education, to improve physical education for changing educational methods. And actively explore new ways to fully exploit the innovative ability to accumulate new experiences, to improve the quality of education is important to ensure that college sports.

"Increasing exercise to teach science, scientific knowledge and methods of fitness, to promote the combination of physical and health education," is the focus of the current reform of college sports. Cultivate students' interest in sports and their capability of exercise independently laid the foundation for lifelong sport, which is a common trend in college sports reform countries. Americans believe that training exercise ability is important than improving technical and physical level, it is also important to emphasize to make students love sports, develop their interest in participating in sports activities and enjoy an enjoyable sports activities to stimulate their longterm participation in physical exercise interest and desire to establish a loving exercise lifestyle. In Japan, while improving motor skills through a variety of reasonable practice, students can experience the fun of sports, cultivate clear, healthy life skills and attitudes, and to focus on health and safety to participate in sports.

In short, the content of physical education increasingly tend to comprehensive, diverse, modern, it requires that on the premise of strengthening basic knowledge, skills transfer and capacity building basic, to enable students to master the most useful and the basic sports knowledge and skills, laid a fundamental to let students engage in physical exercise and lifelong learning.

\section{Tto improve the quality of physical education teachers is a fundamental reform of college sports}

Physical Education, as well as moral, intellectual education, will continue to adapt to the development of society, give full play to their special educational function, and take high-quality training for future health professional's social mission. To achieve this goal is also depends on the improvement and development of university sports teacher quality. Therefore, a high level of training and building new sports teachers is the foundation and guarantee of modern college sports education.

Improve the quality of the new physical education teachers should first change the "conservative" behavior of physical education, actively involved in the reform era. Teachers should strive to improve their overall quality, enrich their cultural awareness, teaching and educating people. When imparting knowledge and skills, teachers should educating students to establish good sportsmanship, develop excellent quality and indomitable will of style. Teachers should strengthen the business of learning to update their knowledge structure and strive to improve their physical education skills.

\section{To strengthen the modern theory teaching is the guidance of college sports reform}

To strengthen the teaching of the theory of modern sports is an important part of college sports reform. Modern theoretical knowledge of sports and college sports practice is match that will directly affect the students 'level of awareness of college sports, will restrict students' lifelong sports awareness and participation. For a long time, physical education in Chinese universities has been conducted by the way of words and deeds, sports and other forms of teaching methods focus only on the skills and they ignored ideological and cultural dimensions. Theory of modern college sports should be multi-angle, multi-form and diversification to enrich, strengthen and enhance students' understanding of the science of sports, it is easy to expand the width and depth of the student sports knowledge.

\section{E. To promote national fitness campaign is the purpose of college sports reform}

As mankind enters the 21 st century, talent training mode gradually change from the "examination-oriented education" to "quality education", the rise of fitness and competitive sports system, education system gradually replaced the traditional theory of interpretation composed of sports people make all kinds of sports form showing the re-integration, allocation of new trends. Obviously, fitness education system covers the structure of the previous sports school sports, mass sports areas, it mainly focuses on loving and landscaping, lifelong health awareness and it combines finance sports, entertainment with social networking applications as a whole, with high practicality, science, lifelong. It was inspired by this trend; the value of college sports will get high marks. It is the most close to the community; it has played an important role in the process of implementing the "National Fitness Program" for the participants, organizers and instructors. It has the most direct and systematic relationship with the healthy development of the "human" physical and psychological, and from the perspective of sports and cultural, it has a influence to the social civilization and progress, affecting the composition of modern high-quality personnel, affecting fitness strategic objectives implementation. But many current investigation showed that, the higher grades in our colleges and universities, the more weak physical fitness consciousness, which is caused by mistakes in college sports. Therefore, we 
must continue to strengthen the educational function of college sports to enhance awareness of physical fitness and health conscious people, so it is very necessary and feasible to carry out nationwide fitness education in Colleges and fitness education

\section{REFERENCES}

[1] Yu Junhua. Research university sports teaching modern educational technology background [J]. Chinese market,2009,09:154-155.

[2] Yu Xun. Research University sports teaching modern educational technology background [J]. Everyone,2010,22:150-151.

[3] Zhou Xia, Liujianping. On the Construction of Modern Educational Technologies aesthetics dual main university teaching mode [J]. Education and Vocational,2007,06:131-132. 